\title{
Safety of users in road evacuation: the logical framework approach in evacuation planning
}

\author{
F. Russo \& C. Rindone \\ LAST - Laboratory for Transport Systems Analysis, \\ DIMET - Department of Computer Science, Mathematics, Electronics \\ and Transportation, Mediterranea University of Reggio Calabria, Italy
}

\begin{abstract}
In this paper an advancement on analysis of the planning process in urban systems in emergency conditions is presented. The internal planning process is analysed according to the Logical Framework Approach. Methods and models resulting from the SICURO project are applied to evaluate a local evacuation plan. The results from experimentations of an evacuation plan for an urban system in emergency conditions are presented.
\end{abstract}

Keywords: planning process, LFA, evacuation, system of models.

\section{Introduction}

The transportation planning process is characterized by different planning dimensions and interactions among the subjects involved. It is possible to identify a dynamic for the adoption of a single plan (internal dynamic process) and a dynamic for progressing among different plans (external dynamic process). Below an internal dynamic process is analysed.

An internal dynamic transportation planning process is affected by objectives to pursue for the implementation of strategies which respect constraints. Starting from analysis of the present situation, in the plan, a set of strategies to adopt for pursuing their objectives is identified, such as to respect constraints.

Effects of alternative scenarios can be simulated and evaluated by applying a system of models. Effects are represented by means of indicators that can be compared with objectives and constraints before implementation of planned interventions (ex ante evaluations). During and after the plan's implementation, interventions have to be monitored to verify by means of a set of indicators ( $e x$ 
post evaluations), whether objectives have been achieved and constraints respected $[11,13]$.

A possible method to evaluate how strategies actually achieve objectives is the Logical Framework Approach (LFA). This is a planning tool according to a results-oriented approach [2, 18]. LFA is applied in planning by numerous countries. In the United States, the LFA has bee applied in the general planning process since 1993 with the Government Performance and Results Act (GPRA) [17]. Many guidelines to implement the LFA are available [7, 3, 8, 4, 13]. The European Union has adopted the LFA to allocate and monitor structural funds [6]. A recent review of the application of the LFA in transportation planning is presented in Rindone [9].

In this paper, transportation planning process in emergency conditions to reduce risk and, in particular, risk exposure, is analysed. Starting from previous results of the SICURO project, analysis focuses on the internal planning process. In particular, the LFA is applied in evacuation planning of an urban system in emergency conditions. Methods and models of the SICURO project are applied to evaluate an urban evacuation plan ex ante. In the project two experiments are carried out to evaluate the plan ex post.

In section 2 the LFA is applied in the transportation planning process in ordinary and emergency conditions. We will refer to the internal process relative to drafting and monitoring a plan. In section 3, guidelines in terms of methods and models of the SICURO project to evaluate an evacuation plan in an urban context are presented. In section 4 , an application in a local emergency plan is presented.

\section{Logical framework approach in transportation planning}

\subsection{Internal transportation planning process}

The internal transportation planning process can be represent adopting the LFA.

A generic plan is represented by the following components:

- inputs, or resources needed to implement the plan;

- activities, or interventions included in the plan;

- outputs, or products and services resulting to carry out activity under the plan;

- outcomes, or purposes, to pursue, in the medium term, after implementation of the plan;

- goals, or general objectives, to pursue, in the long term, after implementation of the plan.

All components are connected by a cause-effect rationale (plan description): starting from available inputs, if activities is implemented then outputs will be delivered, if these outputs are delivered then outcomes will be achieved, if outcomes are achieved then goals will be pursued.

Each component of the plan is measured directly or indirectly by indicators that have to be SMART (Specific, Measurable, Accurate, Realistic and Time bound). For each indicator, a specific target may be assumed. Means of 
verification to estimate and to validate values of each indicators have to be indicated.

Individual components of the plan may be influenced by external factors, that comprise events, conditions and decisions that can be verified independently by the planner.

The plan is represent by a matrix (LOGFrame) constituted by:

- $\quad$ five rows, inputs, activities, outputs, outcomes and goals;

- $\quad$ three columns, indicators, means of verification and external factors.

The LFA can be applied to support ex ante evaluation to identify activities starting from goals (top-down); it can be applied to support ex post evaluation to verify goals starting from activities (bottom-up).

A representation of components and logical connection of generic plan is presented in Figure 1.

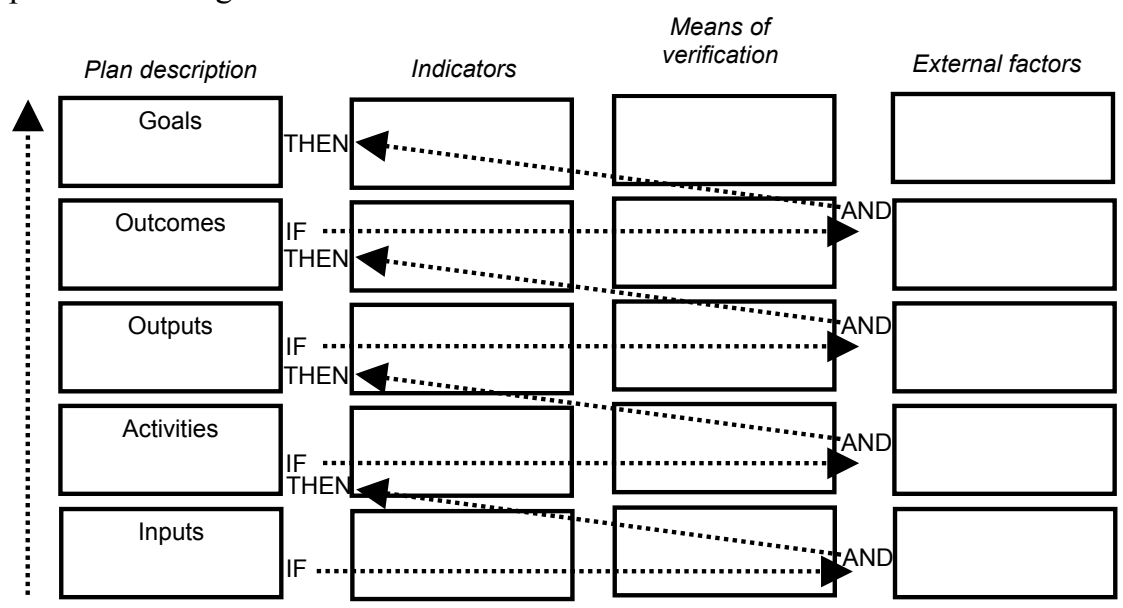

Figure 1: LOGFrame of a generic plan.

\subsection{Transportation planning in emergency conditions}

On adopting an LFA, a transportation plan in evacuation conditions is represented by the following components:

- inputs, needed to implement evacuation procedures, including available resources (human resources, for example, police forces, volunteers, coordinators);

a possible input indicator could be expressed in terms of quantity of available resources (for example number of persons employed during evacuation for organisation);

- activities, that comprise all actions and procedures to prepare an evacuation plan; a possible activities indicator could be expressed in terms of times and number of actions to prepare the plan; 
- outputs, that comprise products and services performed by the activities; a possible output indicator can be expressed in terms of the number of real evacuation tests conducted;

- outcomes, that represent effects of interventions; a possible outcome indicator is expressed in terms of evacuation time;

- goals, that represent final results of the plan; a possible goal indicator is expressed in terms oxf risk reduction.

Means of verification can be represented by methods and models resulting from the SICURO project.

External factors in the emergency planning process can be represented by a set of elements of uncertainty that characterize the context in which evacuation procedures are activated (for example meteorological conditions, malfunctioning of means of communications, unexpected events).

\section{Guidelines for evacuation planning}

The SICURO project results include: guidelines for evacuation planning after a calamitous event; models and procedures to simulate evacuation to verify local emergency plans.

\subsection{Planning dimensions}

It may be assumed that the project results from a regional practicable strategic plan. Guidelines provide indications and tools to design and verify emergency local plans [11].

\subsection{System of models in the emergency planning process}

Methods and models resulting from the SICURO project allow estimation of the evacuation times of an urban area.

This is facilitated by:

- demand models, to estimate trip generation, modal split with distribution [10];

- simulation models of pedestrian outflow in a building, to estimate evacuation times of principal edifices [5];

- simulation models of transport supply-demand interaction for users, to estimate vehicle evacuation times to reach refuge areas [16];

- design of path choice models for emergency vehicles, to estimate times to evacuate weak users and pupils [15];

- $\quad$ simulation models of the refuge area for users, to estimate access times [15].

The evacuation plan can be evaluated ex ante by applying a system of models that allows outcome indicators to be calculated. The same plan can be evaluated ex post by means of real evacuation tests measuring, with a monitoring system, the same outcome indicators calculated ex ante (Figure 2). 


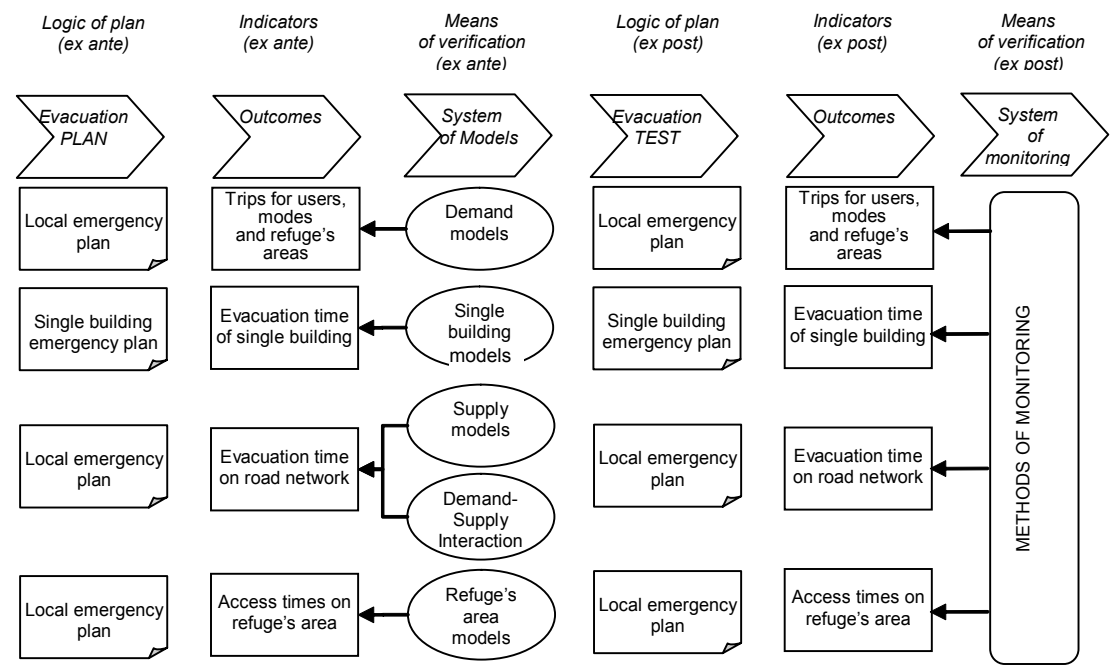

Figure 2: $\quad$ Methods to evaluate outcomes of an evacuation plan.

\section{Validation}

Methods and models resulting from the SICURO project are applied to verify the Local Civil Protection Plan (LCPP) of Melito Porto Salvo in the province of Reggio Calabria in Italy. The plan is tested for a specific event that partly involves the municipal area. The scenario simulated concerns an incident involving a tank transporting hazardous goods which, on a workday morning $(8.00$ am -12.00$)$, is leaking. In the instant $t_{1}$, the presence of a potentially disastrous event is announced. The mayor decides that the surrounding area must be evacuated.

Two evacuation tests are carried out (I test; II test). In the first test the town hall and school buildings are involved. In the second test, besides public buildings, private and commercial buildings in the area are involved. To compare the results of two evacuation tests, the evacuation procedure of public buildings (a town hall and school) will be analysed below.

In this paper a subset of models resulting from the SICURO project is validated by means of ex ante and ex post evaluation of evacuation planning. In section 4.1 the emergency planning process concerning the area is summarised. An application of the LFA and the subset of SICURO models are illustrated in section 4.2 .

\subsection{Emergency planning process}

In the case of the scenario simulated, the Mayor implemented interventions of the LCCP plan. To activate the evacuation procedures for public buildings in the area, the Mayor informed those responsible for evacuation of single buildings, who implemented the procedures indicated in our evacuation plans. 


\subsection{Application in the internal emergency planning process}

Components of the evacuation plans are represented according to the LFA. The system of models resulting from the SICURO project are applied to estimate ex ante evacuation times for the study area. Evacuation times are validated through comparison with ex post measures obtained from the two real evacuation tests.

\section{Inputs}

The inputs considered are those employed in the organisation of evacuation. The input indicator is the human resource involved in each organisational unit.

The indicator is measured ex post in the two evacuation tests. The number of persons involved in the general organisation was the same in the two evacuation tests and equal to 4 . The number of human resources employed in the two tests in the public buildings is reported in Table 1.

Table 1: $\quad$ Comparison of input indicators (ex post).

\begin{tabular}{lcccc}
\hline & \multicolumn{2}{c}{ Ex post (I test) } & \multicolumn{2}{c}{ Ex post (II test) } \\
\hline Human resources employed in organisation & Town hall & School & Town hall & School \\
\hline
\end{tabular}

\section{Activities}

The activities considered are the procedures to set up the LCPP plan, evacuation plans of single buildings and to prepare evacuation tests.

Outputs

The output considered are consists of the real evacuation tests carried out. The output is the number of tests, which amount to two in the SICURO project.

\section{Outcomes}

The outcomes considered are:

- times for evacuation procedures;

- times for evacuation of the town hall;

- times for evacuation of the school;

- times to reach the refuge area.

Times for evacuation procedures are measured ex post in the two tests. With respect to instant $t_{1}$, we measured:

- time interval to inform the Mayor and to activate evacuation procedures $\left(\Delta_{11}\right)$; the time is the same in the two tests and equal to $600 \mathrm{~s}$;

- $\quad$ time interval to inform building managers $\left(\Delta_{12}\right)$;

- time interval to order evacuation of buildings $\left(\Delta_{13}\right)$.

Values measured in the two tests are reported in table 2.

Table 2: $\quad$ Times for evacuation procedures.

\begin{tabular}{lcccc}
\hline & \multicolumn{2}{c}{ Town hall } & \multicolumn{2}{c}{ School } \\
\cline { 2 - 4 } & I test & II test & I test & II test \\
\hline Time interval to inform building managers $\left(\Delta_{12}\right)(\mathrm{s})$ & 1,281 & 768 & 1,159 & 948 \\
Time interval to order evacuation of buildings $\left(\Delta_{13}\right)(\mathrm{s})$ & 1,390 & 1,210 & 1,505 & 1,168 \\
\hline
\end{tabular}


To estimate evacuation times it is necessary to calculate numbers of users in the buildings. This number is evaluated ex ante, applying the model proposed in Russo and Chilà [10]:

$$
\mathrm{d}_{\mathrm{E}, \mathrm{r}}^{\mathrm{k}}(\mathrm{h})=\mathrm{n}_{\mathrm{r}}^{\mathrm{k}}(\mathrm{h}) \cdot \mathrm{m}_{\mathrm{E}}^{\mathrm{k}}(\mathrm{h})
$$

where:

$\mathrm{d}_{\mathrm{E}, \mathrm{r}}^{\mathrm{k}} \mathrm{h}$ (is the number of users in zone $\mathrm{r}$ (town hall or school) present in the period of reference $(h)$;

$\mathrm{n}_{\mathrm{r}}^{\mathrm{k}}(\mathrm{h}) \quad$ is the number of users of category $\mathrm{k}$ in zone $\mathrm{r}$, with $\mathrm{k}$ category index equal to:

W for employees and occasional customers;

$\mathrm{S}$ for schools;

D for weak users;

$\mathrm{m}_{\mathrm{E}}^{\mathrm{k}}(\mathrm{h}) \quad$ calibrating parameter, with $\mathrm{k}$ equal to:

W for employees;

C for occasional customers;

S for schools;

D for weak user.

Values of attributes and parameters to calculate the number of users in the two buildings are reported in table 3 .

Table 3: Attributes and parameters to calculate the number of users in the two buildings.

\begin{tabular}{lccccc}
\hline & \multirow{2}{*}{$\mathrm{m}_{\mathrm{E}}^{\mathrm{k}}(\mathrm{h})$} & \multicolumn{2}{c}{ Town hall } & \multicolumn{2}{c}{ School } \\
\cline { 3 - 6 } & & $\mathrm{n}_{\mathrm{r}}^{\mathrm{k}}(\mathrm{h})$ & $\mathrm{d}_{\mathrm{E}, \mathrm{r}}^{\mathrm{r}}(\mathrm{h})$ & $\mathrm{n}_{\mathrm{r}}^{\mathrm{k}}(\mathrm{h})$ & $\mathrm{d}_{\mathrm{E}, \mathrm{r}}^{\mathrm{r}}(\mathrm{h})$ \\
\hline Employee coefficient $(\mathrm{k}=\mathrm{W})$ & 0.77 & 30 & 23 & - & - \\
Occasional customer coefficient $(\mathrm{k}=\mathrm{C})$ & 0.80 & 30 & 24 & - & - \\
School staff coefficient $(\mathrm{k}=\mathrm{S})$ & 0.88 & - & - & 142 & 125 \\
Weak user coefficient $(\mathrm{k}=\mathrm{D})$ & 1.00 & - & - & - & - \\
\hline
\end{tabular}

Evacuation time of the buildings is calculated ex ante by applying models proposed in Di Gangi and Velonà [5] with a macroscopic approach:

where:

$$
\mathrm{T}_{\mathrm{T}}=\left(\mathrm{f}_{1}+\mathrm{f}_{2}\right) \cdot\left(\mathrm{T}_{\mathrm{A}}+\mathrm{T}_{\mathrm{D}}+\mathrm{T}_{\mathrm{S}}\right)
$$

$\mathrm{T}_{\mathrm{A}} \quad$ is the reaction time;

$\mathrm{T}_{\mathrm{D}} \quad$ is the total time to move along corridors;

$\mathrm{T}_{\mathrm{S}} \quad$ is the total time to move along descending flights;

$\mathrm{f}_{1}, \mathrm{f}_{2}$ are multiplier coefficients assumed equal to 2 and 0.3 .

Running times $\left(T_{D}\right.$ and $\left.T_{S}\right)$ are calculated:

where:

$$
\mathrm{T}_{\mathrm{D}(\mathrm{S})}=\mathrm{L}_{\mathrm{D}(\mathrm{S})} / \mathrm{V}_{\mathrm{D}(\mathrm{S})}
$$

$\mathrm{L}_{\mathrm{D}(\mathrm{S})}$ is the total length to move along corridors (descending flights);

$\mathrm{v}_{\mathrm{D}(\mathrm{S})} \quad$ is the running speed in corridors (descending flights).

Values of attributes, parameters and indicators to measure evacuation times, calculated for the two buildings are reported in Table 4 . The times are calculated for the most distant rooms from the first floor emergency exit assuming the 
number of users. The time is calculated starting from the instant in which the building manager orders evacuation.

Table 4: Attributes, parameters and indicators to measure evacuation times of the buildings.

\begin{tabular}{lcc}
\hline & Town hall & School \\
\hline Number of users to evacuate & 47 & 125 \\
Number of users to evacuate on the first floor & 28 & 80 \\
Number of users to evacuate on the ground floor & 19 & 45 \\
Total length of corridors to run $(\mathrm{m})$ & 15 & 39 \\
Corridor width $(\mathrm{m})$ & 1.5 & 2.9 \\
Corridor density (users $\left./ \mathrm{m}^{2}\right)$ & 1.87 & 0.71 \\
Corridor specific flow $($ users $/(\mathrm{m} \cdot \mathrm{s}))$ & 1.2 & 1.3 \\
Corridor speed $(\mathrm{m} / \mathrm{s})$ & 0.69 & 0.67 \\
Total length of descending flights $(\mathrm{m})$ & 10 & 14.4 \\
Descending flight width $(\mathrm{m})$ & 1.5 & 0.7 \\
Descending flight density $\left(\mathrm{users} / \mathrm{m}^{2}\right)$ & 2.66 & 10.41 \\
Descending flight specific flow $(\mathrm{users} /(\mathrm{m} \cdot \mathrm{s}))$ & 1.3 & 0.88 \\
Descending flight speed $(\mathrm{m} / \mathrm{s})$ & 0.68 & 0.44 \\
Evacation times of building $(\mathrm{s})$ & 121 & 263 \\
\hline
\end{tabular}

The indicators relative to building evacuation times are measured ex post during the two evacuation tests and compared with ex ante evaluation (Table 5).

Table 5: Comparison of the outcome indicators relative to building evacuation time (ex ante and ex post).

\begin{tabular}{lcccccc}
\hline & \multicolumn{2}{c}{ Ex ante } & \multicolumn{2}{c}{ Ex post (I test) } & \multicolumn{2}{c}{ Ex post (II test) } \\
\hline & Town hall & School & Town hall & School & Town hall & School \\
\hline Users to evacuate & 47 & 125 & 50 & 135 & 52 & 137 \\
Evacuation times of building (s) & 121 & 263 & 540 & 254 & 240 & 250 \\
\hline
\end{tabular}

The time taken to reach the refuge area by town hall users $\left(\mathrm{T}_{\mathrm{ev}}^{\mathrm{t}}\right)$ is calculated by applying the models proposed in Vitetta et al. [16]. The time profile of a number of vehicles that reach the refuge's area is estimated. The time considered is relative to the last vehicle that reaches the refuge area. The time taken to reach the refuge area by school users $\left(\mathrm{T}_{\mathrm{ev}}^{\mathrm{s}}\right)$ is calculated by applying the models proposed in Di Gangi and Velonà [5]. The ex ante values are compared with ex post measures (Table 6).

Table 6: Comparison of the outcome indicators relative to time taken to reach the refuge area (ex ante and ex post).

\begin{tabular}{lcccccc}
\hline & \multicolumn{2}{c}{ Ex ante } & \multicolumn{2}{c}{ Ex post (test I) } & \multicolumn{2}{c}{ Ex post (test II) } \\
\hline & Town hall & School & Town hall & School & Town hall & School \\
\hline Time to reach refuge area $\left(\mathrm{T}^{\mathrm{t}, \mathrm{s}}\right.$ ev $)(\mathrm{s})$ & 1,260 & 3,164 & $1,209^{*}$ & 3,230 & 1,302 & 3,273 \\
\hline
\end{tabular}

${ }^{*}$ in test I the refuge area is different from that in test II

Goals

The goal considered is risk $(\mathrm{R})$ reduction. The risk indicator is expressed with Russo and Vitetta's [12] formulation:

$$
\mathrm{R}=\mathrm{P} \cdot \mathrm{V} \cdot \mathrm{N}
$$

where: 
$\mathrm{P} \quad$ is the probability that an emergency event occurs;

$\mathrm{V}$ is vulnerability;

$\mathrm{N}$ is the exposure of people affected during and after the event.

Exposure is evaluated in terms of the number of people present in the evacuation area, relative to single buildings, as the evacuation evolves:

- instant in which the presence of the event is announced, $t=t_{1}$; this is assumed equal to 0 ex ante and ex post;

- $\quad$ instant in which buildings are evacuated, $\mathrm{t}=\Delta_{13}+\mathrm{T}_{\mathrm{T}}$;

- $\quad$ instant in which the area is evacuated and people reach the refuge's area, $\mathrm{t}=$ $\Delta_{13}+\mathrm{T}_{\mathrm{T}}+\mathrm{T}_{\mathrm{t}, \mathrm{ev}}^{\mathrm{s}}$.

Indicators are estimated ex ante and measured ex post in the two tests for the town hall (Table 7) and the school (Table 8). The ex ante value of $\Delta_{13}$ is assumed equal to the minimum time measured in the two tests.

Table 7: Comparison of goal indicators for the town hall (ex ante and ex post).

\begin{tabular}{lcccccc}
\hline & \multicolumn{3}{c}{ Time (s) } & \multicolumn{3}{c}{ Exposure (Persons) } \\
\hline & $\begin{array}{c}\text { Ex } \\
\text { ante }\end{array}$ & $\begin{array}{c}\text { Ex post }(\mathrm{I} \\
\text { test) }\end{array}$ & $\begin{array}{c}\text { Ex post (II } \\
\text { test) }\end{array}$ & Ex ante & $\begin{array}{c}\text { Ex post (I } \\
\text { test) }\end{array}$ & $\begin{array}{c}\text { Ex post (II } \\
\text { test) }\end{array}$ \\
\hline $\begin{array}{l}\text { Event }\left(\mathrm{t}=\mathrm{t}_{1}\right) \\
\begin{array}{c}\text { Building evacuated } \\
\left(\mathrm{t}=\Delta_{13}+\mathrm{T}_{\mathrm{T}}\right)\end{array}\end{array}$ & 0 & 0 & 0 & 47 & 50 & 52 \\
$\begin{array}{c}\text { Area evacuated } \\
\left(\mathrm{t}=\Delta_{13}+\mathrm{T}_{\mathrm{T}}+\mathrm{T}_{\mathrm{ev}}^{\mathrm{t}}\right)\end{array}$ & 2,711 & 1,930 & 1,450 & 47 & 50 & 52 \\
\hline
\end{tabular}

Table 8: $\quad$ Comparison of goal indicators for the school (ex ante and ex post).

\begin{tabular}{lcccccc}
\hline & \multicolumn{1}{c}{ Time $(\mathrm{s})$} & \multicolumn{3}{c}{ Exposure (Persons) } \\
\hline & $\begin{array}{c}\text { Ex } \\
\text { ante }\end{array}$ & $\begin{array}{c}\text { Ex post }(\mathrm{I} \\
\text { test })\end{array}$ & $\begin{array}{c}\text { Ex post (II } \\
\text { test) }\end{array}$ & Ex ante & $\begin{array}{c}\text { Ex post (I } \\
\text { test) }\end{array}$ & $\begin{array}{c}\text { Ex post (II } \\
\text { test) }\end{array}$ \\
\hline $\begin{array}{l}\text { Event }\left(\mathrm{t}=\mathrm{t}_{1}\right) \\
\begin{array}{l}\text { Building evacuated } \\
\left(\mathrm{t}=\Delta_{13}+\mathrm{T}_{\mathrm{T}}\right)\end{array}\end{array}$ & 0 & 0 & 0 & 47 & 50 & 52 \\
$\begin{array}{l}\text { Area evacuated } \\
\left(\mathrm{t}=\Delta_{13}+\mathrm{T}_{\mathrm{T}}+\mathrm{T}_{\mathrm{ev}}^{\mathrm{s}}\right)\end{array}$ & 4,595 & 1,759 & 1,418 & 47 & 50 & 52 \\
\hline
\end{tabular}

Partially supported by Regione Calabria (EU Structural Fund 2000-2006) in the framework of the SICURO project (note no. 19193 of November 23, 2004, on the implementation of measure 3.16 action 3.1.a.3).

\section{References}

[1] Australian Government - AusAID (2005) "AusGuide - A Guide to Program Management” http://www.ausaid.gov.au/ausguide/ (October 2007)

[2] Canadian International Development Agency - CIDA (1997), "CIDA's Business Process RoadMap. Overview" http:/www.acdi-cida.gc.ca/ CIDAWEB/acdicida.nsf/En/JUD-131105815-LQY (October 2007)

[3] Danish International Development Agency - DANIDA (1996), "Danida Logical Framework Approach: A Flexible Tool for Participatory Development"http://amg.um.dk/en/menu/TechnicalGuidelines/LogicalFram eworkApproach/ (October 2007) 
[4] Department for International Development - DFID (2002) "Tools for Development. A handbook for those engaged in development activity", http://www.dfid.gov.uk/pubs/files/toolsfordevelopment.pdf (October 2007)

[5] Di Gangi M., Velonà P. (2007), Deflusso pedonale negli edifici in condizioni di emergenza. Modelli e metodi per la simulazione, applicazione ad un caso reale. Franco Angeli, Milan, Italy.

[6] European Commission (2004), "Project Cycle Management guidelines". EuropeAid Cooperation Office - Development DG http:/ec.europa.eu/ europeaid/reports/pcm_guidelines_2004_en.pdf (October 2007)

[7] German Agency for Technical Corporation - GTZ (1998). "ZOPP - An Introduction to the Method" http://www.serd.ait.ac.th/ ump/html/yellop29.htm (October 2007)

[8] Norwegian Agency for Development Cooperation - NORAD (1999), "The Logical Framework Approach (LFA). Handbook for objectives-oriented planning", Fourth edition, http://www.norad.no/ (October, 2007).

[9] Rindone C. (2007), "Logical Framework Approach nella pianificazione dei trasporti: uno stato dell'arte" Proceedings of XXVIII Italian Conference of Regional Science, Bolzano, Italy

[10] Russo F., Chilà G. (2007), Domanda di trasporto in condizioni di emergenza. Modelli e metodi per la simulazione, applicazione ad un caso reale. FrancoAngeli, Editor, Milan, Italy

[11] Russo F., Rindone C. (2007), Dalla pianificazione alla progettazione dei sistemi di trasporto: processi e prodotti. Franco Angeli, Milan, Italy

[12] Russo F., Vitetta A. (2007), Safety of users in road evacuation: general methodology and main results. In Urban Transport XIII, Brebbia C.A. (ed.), WIT Press, pp. 763-772, ISBN 978-184564-087-3, and in Urban Transport: Safety of Users in Road Evacuation, Russo F. (ed.), WIT Press, pp.1-10, 2007.

[13] Russo F., Vitetta A. (2006), "A Topological Method to Choose Optimal Solutions after Solving the Multi-criteria Urban Road Network Design Problem". Transportation, vol. 33, pp. 347-370.

[14] Swedish International Development Agency - SIDA (2004) “The Logical Framework Approach. A summary of the theory behind the LFA method" http://www.sida.se/sida/jsp/sida.jsp?d=118\&a=2379\&language=en_US (October 2007)

[15] Vitetta A., Assumma, V., Quattrone, A., Polimeni, A. (2007a), Progetto dei percorsi e delle aree di attesa. Modelli e metodi per la simulazione, applicazione ad un caso reale. Franco Angeli, Milan, Italy.

[16] Vitetta A., Musolino G., Marcianò A. (2007b), Offerta e interazione tra domanda e offerta nei sistemi di trasporto in condizioni di emergenza. Modelli e metodi per la simulazione, applicazione ad un caso reale. Franco Angeli, Milan, Italy.

[17] White House, Office of Management and Budget (1993). "Government Performance Results Act of 1993", http://www.whitehouse.gov/omb/mgmtgpra/gplaw2m.html\#h1 (October 2007).

[18] World Bank (2000), "The LogFrame Handbook: A logical framework approach to project cycle management”. Washington, DC: World Bank. 